\title{
Evaluation of Polyherbal Anticancer Tablets: A Review
}

\section{ISHAN DUBEY ${ }^{1 *}$, MANMEET SINGH SALUJA ${ }^{2}$, RITU M GILHOTRA ${ }^{1}$ AND MAHAVIR CHHAJED ${ }^{3}$}

${ }^{1}$ Suresh Gyan Vihar University, Jaipur, Rajasthan, India

${ }^{2}$ Kota College of Pharmacy, Kota, Rajasthan, India

${ }^{3}$ Indore Institute of Pharmacy, Rau, Indore, Madhya Pradesh, India

Email: ishandby@yahoo.com

Received: Feburary. 03, 2018 I Revised: April 04, 2018 | Accepted: April 19, 2018

Published online: May 02, 2018

The Author(s) 2018. This article is published with open access at www.chitkara.edu.in/publications

\begin{abstract}
Cancer is a malignant abnormal growth of cells, one of the most dreaded and complex diseases. It concerns with several tempo spatial changes in cell composition, which finally lead to neoplasia. Various types of cancers have been reported. Chemotherapy, radiation, and/or surgery may cure them. Herbal remedies are supposed to be harmless as they cause fewer complications and are less likely to habitual. Antioxidant compositions of therapeutic plants show the anticancer activity and therefore, use of different proportions of the active components to formulate various standardized preparation with single or multiple components for their synergistic effects play a crucial role in curing cancer. Evaluation parameters to assess the in vitro anticancer activity includes Caspase-3, Caspase-9, alamar blue, LDH assay, XTT assay, sulforhodamine-B assay, MTT assay, DNA fragmentation assay, neutral red uptake cytotoxic assay, tryphan blue assay. Evaluation of dried extract or granules includes bulk density, tapped density, Carr's index, Hausner's ratio, angle of repose while the tablets evaluated by drug-excipient compatibility study by FT-IR, stability studies, hardness, thickness, weight variation, friability, disintegration time and dissolution test.
\end{abstract}

\section{INTRODUCTION}

Malignancy persists to distinguish the leading cause of death in the human race and claims greater than 6 million lives per year (Abdullaev, 2001). An extremely potential approach to prevent cancer is chemotherapy, which is characterized as the utilization of synthetic or natural agents used alone
Journal of Pharmaceutical Technology, Research and Management

Vol-6, No-1, May 2018 pp. 67-79 
Dubey, I

Saluja, MS

Gilhotra, RM

Chhajed, M

or in combinations to obstruct the development of tumor in people. Plants, vegetables and herbs used in the folk and conventional pharmaceuticals have been acknowledged right now as one of the main wellspring of malignancy chemoprevention drug discovery and advancement (Abdullaev, 2000).

Therapeutic plants have been utilized as medicine for individual diseases for a long time. The rationale behind utilizing them as a drug lies in the fact that they have chemical compositions of medicinal values (Nostro A et al, 2000). The therapeutic importance of plants lays in some chemical components usually derivative metabolites that take them into being a specific physiological accomplishment on the human being. Mainly the alkaloids, flavanoids, tannins and phenolic compounds are important biologically active metabolites responsible for the therapeutic significance (Edeoga $\mathrm{HO}$ et al. 2005).

Since1950, the search for anticancer agents from plants origin started and leads to recognition and isolation of the vinca alkaloids, vincristine and vinblastin, the separation of the cytotoxic principles podophyllotoxins (Pezzuto JM, 1997; Reddy L et al.2003). Over $60 \%$ of presently utilized anticancer agents are obtained from natural sources (Cragg GM and Newman DJ, 2003; Balunas MJ and Kinghorn AD, 2005). Some plants that have been assessed and showed prominent antineoplastic potential are Glucyrrhiza glabra, Cinnamomum tamala, Ocimum sanctum, Madhuca longifolia, Emblica officinalis, Adina cordifolia, Aloe barbadensis, Sida Veronicaefolia, Zingiber Officinalis, Terminalia arjuna, Citrus medica, Catharanthus roseus, Nicotiana tabacum, Alium cepa, Allium sativam, Curcuma longa etc. Biologically active metabolites from plants are important source of novel drugs that are likely to lead to development in treatments of variety of cancers. Beside cancer cells, the normal cells are also been destroyed by chemotherapy, and sometimes mutations leads to resistance development in the cancer cells (Wiseman LR and Spencer CM, 1998).Therefore, before the forests are lost to deforestation, screening for the wealth of biodiverse components is imperative for research.

The formulation prepared by plant extracts or complete plant material with appropriate excipients are known as Herbal formulations. These extracts are composed of active constituent, thus with appropriate excipients or base, various formulations are formulated and standardized with suitable technique. formulations with two or more herbs, are known as polyherbal formulations.

To clear the mechanisms in anticancer actions of herbs, it is strongly suggested to get more cellular and molecular studies. For this, various in vitro and in vivo methods have been developed to determine the effectiveness of natural anticancer compounds. In vitro methods like, tryphan blue dye exclusion assay, LDH (Lactic dehydrogenase) assay, MTT assay, XTT assay 
and Sulforhodamine B assay and many more are most commonly used for estimating anticancer properties of natural products from medicinal plants. Dried extract evaluation include determination of Bulk density, Tapped density, Carr's index, Hausner's ratio, Angle of repose while the tablets evaluated by Drug-Excipient Compatibility Study by FT-IR, Stability studies, Hardness, Thickness, Weight Variation, Friability, Disintegration Time, In vitro Dissolution test.

\section{EVALUATION PARAMETERS}

\subsection{In- vitro Evaluation Parameters}

\subsubsection{Caspase-3}

A Cysteine-dependent aspartate-directed proteases known to be Caspases are a class of proteases that cause cell death. A part of the CED-3 subfamily of caspase i.e. Caspase-3 is one of the significant enzymes of apoptosis. Procaspase 2, 6, 7 and 9 processed by Caspase-3, purposely cleaves largely of caspase related substrates, which is a part of the mechanism leading to cell death. The proteins that regulate apoptosis and are inhibitor of caspase-activated deoxyribonuclase gelsolin and fodrin are nuclear enzyme activate poly (ADP-ribose), and polymerase (PARP) (Sakahira H et al, 1998 and Nicholson DW et al, 1995). Mediating nuclear apoptosis, chromatin condensation or DNA fragmentation and cell blebbing, Caspase-3 plays an important role. Its activity in cells and tissues of the body is a sign of cell death (Porter AG and Janicke RU, 1999).

The mechanism of Caspase-3 colorimetric assay is depend upon the hydrolysis of the peptide substrate acetyl-Asp-Glu-Val-Asp p-nitroanilide by Caspase- 3 and leads to release in p-nitroanilide moiety having a high absorbance at $405 \mathrm{~nm}(\Sigma \mathrm{mM}=10.5)$. From the absorbance values at $405 \mathrm{~nm}$, concentration of p-nitroanilide released from the substrate is determined.

$$
\text { Ac-DEVD - pNA } \stackrel{\text { Caspase-3 }}{\longrightarrow} \text { Ac-DEVD + pNA }
$$

The Caspase-3 activation is in apoptosis process (Thornberry NA and Littlewood Y 1998; Wolf BB et al, 1999).

\subsubsection{Caspase-9}

Caspase-9 also known as initiater caspase, a proenzyme that brings cellular apoptosis (Duan H et al, 1996). Caspase-9 become activated at the time of release of mitochondrial cytochrome-c and follows its association with the protein complex of Apaf and cytochrome-c. By protein phosphoylation, active caspase-9 is generated and its cleavage detection sequence is Leu-Glu-His-
Evaluation of

Polyherbal

Anticancer Tablets:

A Review 
Dubey, I

Saluja, MS

Gilhotra, RM

Chhajed, M

Asp-7 (LEHD). Association of caspase-9 with pro-apoptotic, anti-apoptotic proteins and its regulatory function during embryonic development proves that it is a key regulatory enzyme of apoptosis (Petty RD, 1995; Thornberry NA et $a l, 1997)$. The measurement of caspase- 9 activity is possible by a homogenous luminescent assay kit known as Caspase-Glo® 9 . Cell lysis caused by addition of Caspase-Glo®-9 reagents followed by caspase cleavage of the substrate and luciferase reaction that produce luminescent signals that is equivalent to amount of caspase activity present, shows in Figure 1.

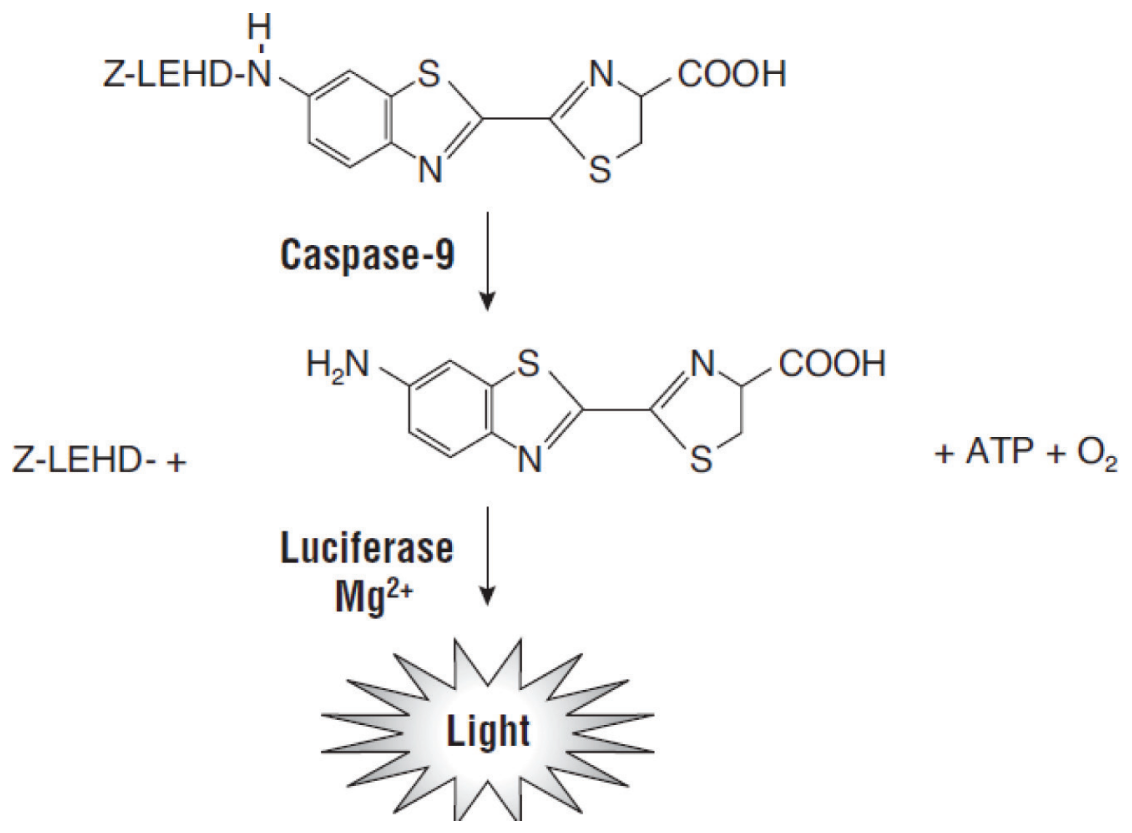

Figure 1: Caspase-9 cleavage of the luminogenic substrate containing the LEHD sequence.

\subsubsection{Alamar Blue Resazurin Reduction Assay}

A suspension of Cell in $100 \mu \mathrm{l}$ of DMEM (Dulbecco's Modified Eagle's Medium) were prepared and seeded in 96-well plates upto the density of $5 \times$ $10^{3}$ cells per well following by incubation for $24 \mathrm{~h}$. A supplemented media were used to dilute the different extracts using a separate 96-well plate followed by incubation for $48 \mathrm{~h}$ after which addition of $100 \mu \mathrm{l}$ of fresh media, (containing $10 \% \mathrm{v} / \mathrm{v}$ of a $860 \mu \mathrm{M}$ solution of resazurin in Phosphate Buffer Saline) to the cells, and incubated for 2 to $4 \mathrm{~h}$. A SpectraMax M5 plate was then employed that reads the fluorescence intensity of the dye by means of excitation at 560 
$\mathrm{nm}$. By the help of an exponential decay curve fit and fluorescence intensity values, IC50 values were calculated. A negative control i.e. DMSO and a a positive control i.e. Nile Blue-A were used (Lin CW et al, 1991).

\subsubsection{LDH assay}

At the time of the pyruvate-lactate transformation, we can measure the activity of Lactic dehydrogenase in the culture medium and in the cellular lysates spectrophotometrically at $340 \mathrm{~nm}$ by analyzing NADH reduction. Break down of cell membrane was done by the addition of a mixture containing $50 \mathrm{mM}$ Tris-HCl buffer of pH 7.4, 20 mM EDTA and $0.5 \%$ Sodium Dodecyl Sulfate to the Cells, and then disrupted by sonication followed by 15 min centrifugion at $13,000 \mathrm{X} \mathrm{g} .1 \mathrm{ml}$ of total final volume of assay mixture having $33 \mu \mathrm{l}$ of sample in $48 \mathrm{mM}$ PBS at $\mathrm{pH} 7.5,1 \mathrm{mM}$ pyruvate and $0.2 \mathrm{mM}$ NADH was used for the enzymatic analysis. The percentage of the entire amount of enzymatic activity present in the cellular lysate and in the culture medium represent the percentage of LDH released (Russo A et al, 2006).

\subsubsection{XTT assay}

For quantification of viable cells, an assay was done by the use of tetrazolium salt (XTT) i.e. (2,3-bis[2-Methoxy-4-nitro-5-sulfophenyl]- 2Htetrazolium5-carboxyanilide. In this assay, mitochondrial enzyme dehydrogenase in living cells cleaved XTT into orange formazan dye and devoid of the employment of radioactive isotopes; spectrophotometric quantification of cell growth and viability was detetmined.

In 96-well plates, cells are grown in growth medium containing $10 \%$ FBS until 70-80\% confluence after that suitable drug sample treated these cells for $24 \mathrm{~h}$. And finally, XTT assay is performed by addition of $50 \mathrm{~mL}$ of XTT labeling mixture solution to each well and the cells are incubated at $37^{\circ} \mathrm{C}$ for 4 h. With the help of a screening multiwell spectrophotometer reader, the control wells is compared with aqueous soluble formazan dye having the optical density at $450 \mathrm{~nm}$ by taking $650 \mathrm{~nm}$ reference wavelength using ELISA reader (Economou MA et al, 2008).

\subsubsection{Sulforhodamine-B assay}

Assay is based on dissociation of Sulforhodamine B (a bright pink aminoxanthene dye) under basic condition and binds to basic amino acids in mild acidic conditions. Different cell numbers plated i.e. 5000-10000 \zcell/ well are available for adjusting differences in the growth rates of the various cell lines. Cells are plated in 96-well flat bottom plates and are allowed to
Evaluation of

Polyherbal

Anticancer Tablets:

A Review 
Dubey, I

Saluja, MS

Gilhotra, RM

Chhajed, M

stick to the wells overnight, and then in serial 3-fold dilutions the samples are added to triplicate wells. Water is added to the control wells at a 1:10 dilution in medium and for 3 days at $37{ }^{\circ} \mathrm{C}$ and $5 \% \mathrm{CO}_{2}$ plates are incubated and by using a sulforhodamine $\mathrm{B}$ assay growth inhibition is determined.

For fixation of cells, $10 \%$ volume of cold $50 \%$ trichloroacetic acid is added and incubated for $1 \mathrm{~h}$ at $4{ }^{\circ} \mathrm{C}$, after that wash the cells with deionized water at least five times. Staining the cells for $15-30 \mathrm{~min}$ by the addition of $0.4 \% \mathrm{SRB}$ in $1 \%$ acetic acid and then wash these cells five times with $1 \%$ acetic acid to remove unbound stain. Dry these plates at room temperature and by using 10 $\mathrm{mm}$ Tris base the bound dye is solubilised and analysing these plates at $595 \mathrm{~nm}$ on a microplate reader (Skehan P et al, 1990).

$$
\% \text { growth inhibition }=\frac{\text { Control sample }}{\text { Control }} \times 100
$$

\subsubsection{MTT Assay}

It is a colorimetric assay to determine the metabolic activity of of viable cells. The enzymes cellular oxidoreductase occurs in metabolically active cells converts MTT, a yellow tetrazolium salt ([3- (4, 5-dimethylthiazolyl)-2, 5-diphenyltetrazolium bromide]) by into purple-formazan crystals, that reflecting number of viable cells.

For plating the cells a 96 well plates at a cell density of $2 \times 10^{5}$ per $\mathrm{mL}$ per well in $100 \mu \mathrm{L}$ of RPMI 1640 are used. For incubation of cells, $\mathrm{CO}_{2}$ incubator is used for $24 \mathrm{~h}$ at $37^{\circ} \mathrm{C}$ and $5 \% \mathrm{CO}_{2}$ that allow cells to grow. After incubation medium is removed and a fresh medium with different sample concentrations is added for $48 \mathrm{~h}$. Again these cells are incubated for $24-48 \mathrm{~h}$ at $37^{\circ} \mathrm{C}$ and $5 \%$ $\mathrm{CO}_{2}$. Then each well is treated with $20 \mu \mathrm{L}$ MTT stock solution in PBS (5mg/ $\mathrm{mL}$ ) and incubated for $5 \mathrm{~h}$. To dissolve the MTT metabolic product, removing the medium and add $200 \mu \mathrm{L}$ DMSO to each well and shake the plate at 150 rpm for $5 \mathrm{~min}$ and measured the optical density is at $560 \mathrm{~nm}$. For control of viability (100\%), untreated cells (basal) are used and by using \% viability (log) relative to the control, results are determined(Mossman T 1983).

\subsubsection{DNA Fragmentation Assay}

For this assay, 60mm Petri dishes were taken and HeLa cells $\left(3 \times 10^{6} / \mathrm{ml}\right)$ were seeded on it and allow incubating for $24 \mathrm{~h}$ at $37^{\circ} \mathrm{C}$ with $5 \% \mathrm{CO}_{2}$. Then wash the cells with medium. Add extract and standard drug and incubate the cells for $24 \mathrm{hrs}$ at $37^{\circ} \mathrm{C}, 5 \% \mathrm{CO}_{2}$. After completion of incubation, use the apoptotic DNA ladder kit for preparation of chromosomal DNA of cancer cells. Then gel 
electrophoresis technique was use in which recovered DNA was loaded onto $2 \%$ agarose. Running time was $3 \mathrm{hrs}$ for $50 \mathrm{~V} / \mathrm{cm}$. For gel visualization, UV transilluminator was used and photographed (Sirimal GK, 2015).

\subsubsection{Neutral Red Uptake Cytotoxic assay}

To perform this assay, dissolve $3.3 \mathrm{gm}$ of Neutral Red dye in $100 \mathrm{ml}$ of double distilled water and filter this stock solution by syringe filter and then stored it at room temperature. This stock solution was then better used within 6 months.

Take $99 \mathrm{ml}$ of culture media with $1 \mathrm{ml}$ of Neutral Red stock solution and finally get $0.33 \%$. Previously incubated Cell plates were taken and the culture media from the plates were removed and add the extract containing culture media. To get the appropriate action of extract, the plates were incubated for $24 \mathrm{hrs}$ in $\mathrm{CO}_{2}$ incubator. The Neutral Red containing medium replace the extract containing culture media and depending upon cell type, cells were again incubatefor 4-8 hours. After incubation, remove the medium cautiously and wash the cells immediately with PBS. Eliminate the washed solution and finally dye was solubilized by means of Neutral Red Assay Solubilization Solution i.e. ethanolic and acetic acid in the quantity equal to the original quantity of culture medium.

Now at room temperature, keep the plates to stand for 10 minutes. To improve mixing of the solubilized dye, gyratory shaker was used. With ELISA reader, optical density of background absorbance was calculated at $540 \mathrm{~nm}$ and pictures were captured using microscope (Mosmann T, 1983).

Calculation of $\%$ inhibition was done by using the formula

$$
\begin{aligned}
& \% \text { inhibition } \\
& =\frac{\text { Optical density of untreated }- \text { Optical density of drug Treated }}{\text { Optical density of untreated }} \times 100
\end{aligned}
$$

\subsubsection{Tryphan Blue assay}

Assay is based on testing the cell viability leaving out by the trypan blue dye. Hank's Buffered Salt Solution (HBSS) is used to wash the cells and centrifuged at $10,000 \mathrm{rpm}$ for $10-15 \mathrm{~min}$. Repeat this procedure three times. Suspend the cells in known amount of HBSS and adjust the cell count to $2 \times 10^{6}$ cells $/ \mathrm{ml}$. Eppendorf tubes is taken to distribute the cell suspension. The cells are treated with drug dilutions and incubate for $3 \mathrm{~h}$ at $37^{\circ} \mathrm{C}$. After incubation, perform the dye exclusion test. In this test, same amount of the drug treated cells are mixed with tryphan blue $(0.4 \%)$ and leave it for $1 \mathrm{~min}$. A haemocytometer loaded
Evaluation of

Polyherbal

Anticancer Tablets:

A Review 
Dubey, I

Saluja, MS

Gilhotra, RM

Chhajed, M

with above mixture to record viable and non-viable count within $2 \mathrm{~min}$. Dye transverses into dead cells while viable cells do not absorb colour and remain colourless (Unnikrishnan MC and Ramadasan K, 1998).

Formula for calculating $\%$ growth inhibition is

$$
\text { Growth inhibition }(\%)=100-\frac{(\text { Totalcells-Dead cells })}{\text { Total cells }} \times 100
$$

\subsection{Evaluation of Dried Extract or Granules}

\subsubsection{Bulk density $\left(\mathrm{D}_{\mathrm{B}}\right)$}

Lumps produced in the sample at the time of storage are finally broken up by passing the sample through sieve no. 18. Take a $100 \mathrm{ml}$ graduated cylinder and transfer the sample to it by avoiding any compacting. Take bulk volume ( Vb) upto the nearest unit and calculate the bulk density by using formula (United States Pharmacopoaeia, 2003).

Unit of bulk density is $\mathrm{gm} / \mathrm{cm}^{3}$

$$
\mathbf{D}_{\mathbf{B}}=\mathbf{M} / \mathbf{V b}
$$

Where, $\mathrm{M}=$ weight of the sample and $\mathrm{Vb}=$ mean bulk volume of the sample.

\subsubsection{Tapped density $\left(D_{T}\right)$}

Take a $100 \mathrm{ml}$ measuring cylinder and poured the screened sample at an angle of about $45^{\circ}$ keep the measuring cylinder on a Stampfvolumeter and start tapping till no more changes occurs in volume and note the constant volume (United States Pharmacopoaeia, 2003).

$$
\mathrm{D}_{\mathrm{T}}=\frac{\mathrm{M}}{\mathrm{V}_{\mathrm{T}}}
$$

Where, $\mathrm{M}=$ weight of the sample and $\mathrm{V}_{\mathrm{T}}=$ tapped volume of the sample.

\subsubsection{Carr's index}

The Carr's index is the tendency of a powder to be compressed and it is depend upon bulk and tapped density of that powder. According to 
the theory, less compressible material is more flowable. Hence a free flowing powder has less significant interactions and therefore their values for bulk and tapped densities will be closer. Materials with poor flow have greater inter-particle interactions, and therefore their values for bulk and tapped densities will have greater difference (Khandelwal KR, 2009; Kokate CK, 2008).

Compressibility index formula can calculate this difference

$$
\begin{gathered}
\text { Compressibilityindex }=\frac{D T-D B}{D T} \times 100 \\
\text { Where, } D_{B}=\text { Bulk Density, } D_{T}=\text { Tapped Density }
\end{gathered}
$$

\subsubsection{Hausner's ratio (HR) Compressibility index (CI $)^{[33]}$}

The Hausner ratio (HR) and Compressibility index (CI) of the samples can be determined by using the formula

$$
\mathbf{H R}=\mathrm{D}_{\mathrm{T}} / \mathrm{D}_{\mathrm{B}}
$$

Hausner's ratio less than 1.25 shows better flow properties, between 1.25 to 1.5 shows moderate flow properties and greater than 1.5 shows poor flow (Paronen P and Ikka J, 1995).

\subsubsection{Angle of repose and Flow Rate}

To determine angle of repose and flow rate the fixed-height cone technique was employed. Keep a glass funnel above a plane horizontal surface and fixed it at a $10 \mathrm{~cm}$ height by blocking its exit with a flat ruler. Spread a fresh white paper on the horizontal surface below the funnel for powder collection. Poured the specific weighed amount of sample into the funnel and unblock the exit of the funnel and by the help of a stop clock note the time required for the sample to totally flow out onto the paper. Measure the height and radius of the heap and calculate the flow rate and angle of repose (Carter SJ, 1986).

\section{Flow rate $=M / t$}

\section{Angle of repose $=\tan A=h / r$}

Where $\mathrm{M}=$ mass of the sample in grams, $\mathrm{t}=$ time taken for the sample to completely flow out of the funnel in seconds, $\mathrm{A}=$ angle (o) formed by the sample cone, and $\mathrm{h}=$ height of the sample cone formed after flowing from the funnel in $\mathrm{cm}$.
Evaluation of

Polyherbal

Anticancer Tablets:

A Review 
Dubey, I

Saluja, MS

Gilhotra, RM

Chhajed, M

\subsection{Evaluation of tablets}

\subsubsection{Drug-Excipients Compatibility Study by FT-IR}

FT-IR spectral analysis is used to detect any modification on chemical composition of the drug when it gets combined with the excipients Compatibility of the drug with excipients was determined by this study. The spectra of drug in $\mathrm{KBr}$ pellets are scanned between $4000-400 \mathrm{~cm}-1$ in IR that shows the peak values for probable different functional group which will compare with standard value to determine the purity of sample (Margret $\mathrm{C}$ and Jayakar B, 2010).

\subsubsection{Stability studies}

Optimized drug formulation for determination of stability studies is subjected to different specified storage condition of temperature and relative humidity.

For long term- $25^{\circ} \mathrm{C} / 60 \% \mathrm{RH}$ for 12 months

For intermediate- $30^{\circ} \mathrm{C} / 60 \%$ RH for 6 months

For accelerated $-40^{\circ} \mathrm{C} / 75 \% \mathrm{RH}$ for 3 months ( $\mathrm{ICH}$ harmonised tripartite guideline stability testing of New drug substances and products, 2003)

\subsubsection{Hardness and friability}

Monsanto tablet hardness tester is used to determine hardness of tablet. Randomly select tablets to perform the test from each batch.

Roche friabilator is used to determine in weight of previously weighed randomly selected twenty tablets for $4 \mathrm{~min}$. at $25 \mathrm{rpm}$. Remove the dust from tablets and calculate the percentage loss.

$$
\% \text { Friability }=\frac{\text { Lossin weight }}{\text { Initial weight }} \times 100
$$

\subsubsection{Thickness}

By the use of Vernier calipers thickness of tablet was determine. To perform the test 6 tablets are taken, and kept between two jaws of calipers and determine the thickness in $\mathrm{mm}$.

\subsubsection{Weight Variation}

By using $1 \mathrm{mg}$ sensitivity balance, select 20 tablets randomly from every formulation and weigh individually. Compare the average weights to individual tablet weights. 


\subsubsection{Disintegration Time}

USP disintegration apparatus is used to perform disintegration test. Six tablets are taken, container filled with $900 \mathrm{ml}$ distilled water or buffer and maintained at $37 \pm 2{ }^{\circ} \mathrm{C}$. Note the time require to disintegrate all the tablets completely.

\subsubsection{In vitro Dissolution test}

USP dissolution test apparatus is used to perform dissolution test. Put two tablets in each of 6 dissolution vessels containing $900 \mathrm{ml}$ of distilled water or buffer solution maintained at $37 \pm 0.2^{\circ} \mathrm{C}$. Withdraw $10 \mathrm{ml}$ aliquots at $10,20,30,40,50$ and 60 min time interval and filter them by the help of wattman filter paper. Put back equal amount of fresh dissolution medium after each withdrawal. This samples are then tested in UV spectrophotometer and determine the percentage drug release using a standard curve (Mishra S U et al, 2011).

\section{REFERENCES}

1. Abdullaev, F.I., R.R. Luna, B.V. Roitenburd, A.J. (2000). Espinosa, Pattern of childhood cancer mortality in Mexico. Arch. Med. Res., 31, 526-31. https://doi.org/10.1016/S0188-4409(00)00094-1

2. Abdullaev, F.I., (2001). Plant-derived agents against cancer. In: Pharmacology andTherapeutics in the New Millennium, New Delhi. 345-354.

3. Balunas MJ, Kinghorn AD (2005). Drug discovery from medicinal plants. Life Sci. 78, 431-441. https://doi.org/10.1016/j.lfs.2005.09.012

4. Carter SJ (1986). Powder Flow and Compaction: In: Cooper and Gun's Tutorial Pharmacy. 2nd Ed. CBS Publishers and Distributors, India. 186-232.

5. Cragg GM, Newman DJ (2003). Plants as a source of anti-cancer and anti-HIV agents. Ann. Appl. Biol. 143, 127-133. https://doi.org/10.1111/j.1744-7348.2003.tb00278.x

6. Duan $\mathrm{H}$ et al.,(1996). ICE-LAP3, a novel mammalian homologue of the Caenorhabditis eleganscell death protein Ced-3 is activated during Fas- and tumor necrosis factor-induced apoptosis. Journal Biochemistry 271, 1621-1625.

7. Economou MA et al., (2008).Oral picropodophyllin (PPP) is well tolerated in vivo and inhibits IGF-1R expression and growth of uveal melanoma. Acta Ophthalmologica; 86, 35-41. https://doi.org/10.1111/j.1755-3768.2008.01184.x

8. Edeoga HO, Okwu DE, Mbaebie BO (2005). Phytochemical constituents of some Nigerian medicinal plants. Af.r. J Biotechnol. 4, 685-688.

https://doi.org/10.5897/AJB2005.000-3127

9. ICH harmonised tripartite guideline stability testing of New drug substances and products. Q1A(R2). Current Step 4 version, 2003.
Evaluation of

Polyherbal

Anticancer Tablets:

A Review

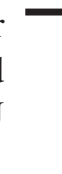


Dubey, I

Saluja, MS

Gilhotra, RM

Chhajed, M

10. Khandelwal KR (2009). Practical Pharmacognosy,19th ed: Nirali Prakashan, Pune, 146-165.

11. Kokate CK (2008). Practical Pharmacognosy, 4th ed, Nirali Prakashan,Pune, India. 10-27

12. Lin CW et al., (1991). Lysosomal localization and mechanism of uptake of Nile blue photosensitizers in tumor cells. Cancer Res. 51, 2710-2719.

13. Margret C, Jayakar B (2010). Formulation and evaluation of herbal tablets containing ipomoea digitata linn. Extract. International Journal of Pharmaceutical Sciences Review and Research. 3(1), 101-110.

14. Mishra S U, Murthy P N, Pasa G, Mishra D (2011). Formulation development and evaluation of herbal tablet containing methanolic extract of butea frondosa. International journal of Institutional Pharmacy and life sciences. 1(3), 1-15.

15. Mossman T (1983). Rapid colorimetric assay for cellular growth and survival: application to proliferation and cytotoxicity assays. J Immunol Methods; 65, 55-63. https://doi.org/10.1016/0022-1759(83)90303-4

16. Nicholson DW, Ali A and Thornberry NA. (1995). Identification and inhibition of the ICE/CED-3 protease necessary for mammalian apoptosis. Nature 376, 37-43. https://doi.org/10.1038/376037a0

17. Nostro A et al.,(2000). Extraction methods and bioautography for evaluation of medicinal plant antimicrobial activity. Lett. Appl. Microbiol. 30, 379-384. https://doi.org/10.1046/j.1472-765x.2000.00731.x

18. O'Brien J, Wilson I, Orton T, Pognan F (2000). Investigation of the Alamar (resazurin) fluorescent dye for the assessment of mammalian cell cytotoxicity. Eur. J. Biochem. 267, 5421-5426. https://doi.org/10.1046/j.1432-1327.2000.01606.x

19. Paronen P, Ikka J (1995). Porosity-pressure functions. In: Pharmaceutical powder compaction technology. Alderborn G, Nystrum C. (Eds), Marcel Dekker, New York 71, 55-75. https://doi.org/10.1201/b14207-4

20. Pezzuto JM (1997). Plant-Derived Anticancer Agents. Biochem.Pharmacol. 53, 121-133. https://doi.org/10.1016/S0006-2952(96)00654-5

21. Petty RD (1995). Comparison of MTT and ATP-based assays for the measurement of viable cell number. Journal of Biolumin. Chemilumin. 10, 29-34. https://doi.org/10.1002/bio.1170100105

22. Porter AG and Janicke RU (1999). Emerging roles of caspase-3 in apoptosis. Cell Death Differentation 6, 99-104. https://doi.org/10.1038/sj.cdd.4400476

23. Reddy L, Odhav B, Bhoola KD (2003). Natural products for cancer prevention: a global perspective. Pharmacology \& Therapeutics. 99, 1-13. https://doi.org/10.1016/S0163-7258(03)00042-1

24. Russo A et al., (2006). Pannarin inhibits cell growth and induces cell death in human prostate carcinoma DU- 145 cells. Anti-Cancer Drugs; 17, 1163-1169. https://doi.org/10.1097/01.cad.0000236310.66080.ed 
25. Sakahira H, Enari M and Nagata S (1998) Cleavage of CAD inhibitor in CAD activation and DNA degradation during apoptosis. Nature 391, 96-99. https://doi.org/10.1038/34214

26. Sirimal GK (2015). In vitro cytotoxic studies of various formulations of Indian medicinal plants. Indian Journal of Research in Pharmacy and Biotechnology. 3(3), 210-217.

27. Skehan P et al., (1990) New colorimetric cytotoxicity assay for anticancer drug screening. J Natl Cancer Inst; 82, 1107-1112.

https://doi.org/10.1093/jnci/82.13.1107

28. Thornberry NA et al., (1997). A combinatorial approach defines specificities of members of the caspase family and granzyme B. Functional relationships established for key mediators of apoptosis. Journal of Biochemistry 272, 17907-17911. https://doi.org/10.1074/jbc.272.29.17907

29. Thornberry NA and Littlewood Y (1998).Caspases Enemies Within. Science 281, 1312-1316. https://doi.org/10.1126/science.281.5381.1312

30. United States Pharmacopoaeia (2003). Bulk Density and Tapped Density. Asian Ed.; 26, 2125.

31. UnnikrishnanMC,RamadasanK(1998).Cytotoxicityofextractsofspicestocultured cells. Nutr Cancer; 11, 251-257. https://doi.org/10.1080/01635588809513995

32. Wiseman, LR, Spencer CM (1998). Drugs Aging 12, 305-334. https://doi.org/10.2165/00002512-199812040-00005

33. Wolf BB, Schuler M, Echeverri F, Green DR (1999). Caspase-3 is the primary activator of apoptotic DNA fragmentation via DNA fragmentation factor-45/ inhibitor of caspase-activated DNase inactivation. Journal Biochemistry 274, 30651-30656. https://doi.org/10.1074/jbc.274.43.30651
Evaluation of

Polyherbal Anticancer Tablets:

A Review 